32 Hagberg B, Hagberg G, Olow I. The changing panorama of cerebral palsy in Sweden. IV. Epidemiological trends 1959-1978. Acta Paediatr Scand 1984;73:433-40.

33 Paneth N, Rudelli R, Monte W, Rodriguez E, Pinto J, Kairam R, Kazam E. White matter necrosis in very low birth weight infants: Neuropathologic and ultrasonographic findings in infants surviving six days or longer. $\mathcal{F}$ Pediat 1990;116:975-84

34 Armstrong DL, Sacks CP, Goddard-Firegold J. Neuropathologic findings in short-term survivors of intraventricular haemorrhage. Am $\mathcal{F}$ Dis Child 1987;141:617-21.

35 Freeman JM, Nelson KB. Intrapartum asphyxia and cerebral palsy. Pediatrics 1988;82:240-50.
36 Barth PG. Disorders of neuronal migration. Le fournal Canadien des Sciences Neurologiques 1987;14:1-16.

37 Sarnat HB. Disturbances of late neonatal migrations in the perinatal period. Am $\mathcal{F}$ Dis Child 1987;141:969-80.

38 Stanley FJ, Sim M, Wilson G, Worthington S. The decline in congenital rubella syndrome in Western Australia: an impact of the school girl vaccination program? Am $\mathcal{F}$ Publ Health 1986;76:35-9.

39 Pharoah POD, Buttfield IH, Hetzel BS. Neurological damage to the fetus resulting from severe iodine deficiency during pregnancy. Lancet $1971 ; \mathrm{i}$ 308-10

(Accepted 27 April 1992)
Department of

Neurosurgery, Helsinki

University Hospital, SF-00260 Helsinki, Finland Seppo Juvela, neurosurgeon

Correspondence and reprint requests to: Dr Seppo Juvela, Department of Neurosurgery, Helsinki University Hospital, Topeliuksenkatu 5, SF-00260 Helsinki, Finland.

BMf 1992;304:1663-7

\title{
Alcohol consumption as a risk factor for poor outcome after aneurysmal subarachnoid haemorrhage
}

\author{
Seppo Juvela
}

\begin{abstract}
Objective-To evaluate the effect of factors existing before aneurysmal subarachnoid haemorrhage on outcome of haemorrhage.

Design-Prospective follow up study.

Setting-Helsinki University Hospital.

Patients-291 consecutive patients (149 men) aged 15 to 65 years admitted within 96 hours after the bleeding.

Main outcome measures-Potential risk factors (baseline characteristics, health habits, and clinical variables) for poor outcome after haemorrhage (dependent state in the activities of daily living, or death) were studied using multiple logistic regression.
\end{abstract}

Results-One year after haemorrhage, $179(62 \%)$ patients were independent in the activities of daily living and $28(10 \%)$ dependent; $84(29 \%)$ had died. Risk of poor outcome was predicted, after adjustment for sex and age, by clinical condition at admission according to the Glasgow coma scale $(\mathbf{p}<\mathbf{0 . 0 0 0 1})$; occurrence of rebleeding (relative risk $7 \cdot 1,95 \%$ confidence interval $2 \cdot 8$ to $18 \cdot 0, p<0 \cdot 0001$ ) or delayed cerebral ischaemia $(10.3,4.2$ to 25.4 , p $<0.0001)$; surgery on an aneurysm $(0.13,0.05$ to $0.35, \mathrm{p}<0.0001$ ); and heavy consumption of alcohol $(4.5,1.8$ to $11.0, p=0.0014)$. Heavy drinking remained a significant risk factor after additional adjustment for hypertension, body mass index, and presence of intracerebral haematoma. Heavy drinkers had a more unfavourable outcome after rebleeding and delayed ischaemia than did others with rebleeding or ischaemia. Those who had salicylates in urine on admission had delayed ischaemia with fixed neurological deficits less commonly than others.

Conclusions-Heavy drinking impairs outcome mainly through severe rebleeding and delayed ischaemia and to a lesser extent through a poor initial condition and presence of intracerebral haematoma.

\section{Introduction}

Aneurysmal subarachnoid haemorrhage is a serious disease with high mortality and morbidity. Delayed cerebral ischaemia and rebleeding are the most important causes of death and disability, after the primary bleed. ${ }^{1-3}$ The risk of delayed ischaemia is best predicted by the amount of subarachnoid ${ }^{46}$ and intraventriculars blood, as well as by previous hypertension, ${ }^{6}$ irrespective of clinical condition on admission or hydrocephalus. There are no uniformly accepted predictive risk factors for rebleeding except the administration of antifibrinolytic drugs, which reduce this risk. ${ }^{45}$ The overall outcome can best be predicted by the initial clinical condition and the amount of subarachnoid blood as a poor initial condition is associated with mortality due to the primary bleed. ${ }^{4}$

Besides these independent risk factors, which are associated with the severity of haemorrhage, there may also be pre-ictal factors other than hypertension that can impair the outcome. It is not known whether alcohol consumption, smoking, or the use of nonsteroidal anti-inflammatory drugs influence outcome. Alcohol consumption, especially heavy drinking, has been shown to increase the risk of all types of stroke, ${ }^{7-11}$ while smoking increases the risk of subarachnoid haemorrhage ${ }^{12-15}$ and cerebral infarction..$^{11115}$ Use of non-steroidal anti-inflammatory drugs seems to increase the risk of haemorrhagic stroke. ${ }^{16}$ Hence, these factors might also impair outcome after subarachnoid haemorrhage by making patients prone to cerebral ischaemia, rebleeding, or a severe initial bleed. Awareness of factors worsening the outcome could be important in the management of subarach noid haemorrhage. This prospective study investigated the influence of these factors on the outcome after subarachnoid haemorrhage.

\section{Patients and methods}

From January 1985 to September 1986 a total of 291 patients with aneurysmal subarachnoid haemorrhage were admitted to the Helsinki University Hospital. After they had been admitted, I interviewed patients, their family members, and fellow workers, as appropriate, about smoking and alcohol habits, use of medicines, and previous diseases of the patient. Data were obtained solely from the patients themselves in 42 cases and from family members only in 55 cases or fellow workers only in six cases when the patient was in poor condition. In the remaining 188 cases information was obtained from both patients and family members. In about a quarter of these cases either the patient or the family member underestimated or overestimated alcohol intake. Because underestimation is more likely in alcohol intake, the greater amounts reported in these cases were registered.

Alcohol consumption, both recent and long term, was calculated from the amount of alcohol consumed before haemorrhage. Patients with two or more positive answers to the four questions in the CAGE interview were considered to be "CAGE positive," a classification that correlates well with heavy drinking. ${ }^{17}{ }^{18} \mathrm{On}$ admission, blood samples were obtained for measurement of markers of alcohol intake (erythrocyte mean cell volume, $\gamma$-glutamyltransferase concentration, and platelet count). Cigarette smoking was categorised as never smoked, former smoker, and current smoker$\leqslant 10,11-20>20$ cigarettes a day, respectively. Use of 
TABLE I-Clinical characteristics and outcome in patients with aneurysmal subarachnoid haemorrhage. Values are numbers (percentages)

\begin{tabular}{|c|c|c|}
\hline Characteristic & $\begin{array}{l}\text { All patients } \\
(\mathbf{n}=291)\end{array}$ & $\begin{array}{l}\text { Patients } \\
\text { undergoing } \\
\text { surgery } \\
(\mathrm{n}=204)\end{array}$ \\
\hline \multicolumn{3}{|c|}{ Clinical grade (Hunt and Hess $\left.^{20}\right):^{\star}$} \\
\hline \multicolumn{3}{|c|}{ On admission } \\
\hline I & $51(18)$ & $44(22)$ \\
\hline II & $101(35)$ & $88(43)$ \\
\hline III & $77(26)$ & $56(27)$ \\
\hline IV & $32(11)$ & $13(6)$ \\
\hline $\mathrm{v}$ & $30(10)$ & $3(1)$ \\
\hline \multicolumn{3}{|l|}{ Before surgery } \\
\hline I & & $85(42)$ \\
\hline II & & $45(22)$ \\
\hline III & & $63(31)$ \\
\hline IV & & $6(3)$ \\
\hline V & & $5(2)$ \\
\hline \multicolumn{3}{|c|}{$\begin{array}{l}\text { Clinical grade (Glasgow coma scale }{ }^{19} \text { ) } \\
\text { on admission: }\end{array}$} \\
\hline $3-6$ & $33(11)$ & $4(2)$ \\
\hline $7-9$ & $15(5)$ & $4(2)$ \\
\hline $10-12$ & $19(7)$ & $12(6)$ \\
\hline $13-14$ & $70(24)$ & $50(25)$ \\
\hline 15 & $154(53)$ & $134(66)$ \\
\hline \multicolumn{3}{|l|}{$\begin{array}{l}\text { Intracerebral haematoma } \\
(\geqslant 10 \mathrm{~mm} \text { diameter }):\end{array}$} \\
\hline No & $216(74)$ & $162(79)$ \\
\hline Yes & $75(26)$ & $42(21)$ \\
\hline \multicolumn{3}{|l|}{ Rebleeding } \\
\hline No & $230(79)$ & $183(90)$ \\
\hline Yes & $61(21)$ & $21(10)$ \\
\hline \multicolumn{3}{|c|}{ Delayed cerebral ischaemia $\nmid$} \\
\hline No & $170(65)$ & $120(59)$ \\
\hline Reversible deficit & $36(14)$ & $35(17)$ \\
\hline Fixed deficit & $54(21)$ & $47(23)$ \\
\hline \multirow{2}{*}{\multicolumn{3}{|c|}{$\begin{array}{l}\text { Outcome at one year } \\
\left.\text { (Glasgow outcome scale }{ }^{21}\right) \text { : }\end{array}$}} \\
\hline & \multicolumn{2}{|c|}{$\begin{array}{l}\text { (Glasgow outcome scale }) \text { : } \\
\text { Good recovery of minimal }\end{array}$} \\
\hline $\begin{array}{l}\text { Good recovery of } \mathrm{mi} \\
\text { disability }\end{array}$ & $150(52)$ & $136(67)$ \\
\hline Moderate disability & $29(10)$ & $25(12)$ \\
\hline Severe disability & $25(9)$ & $24(12)$ \\
\hline Vegetative state & $3(1)$ & $3(1)$ \\
\hline Dead $\ddagger$ & $84(29)$ & $16(8)$ \\
\hline
\end{tabular}

^Hunt and Hess grades: $1=$ no symptoms or minimal headache and slight nuchal rigidity; $2=$ moderate to severe headache, nuchal rigidity, no neurologic deficit except possible cranial nerve palsy; $3=$ drowsiness, confusion, or mild focal deficit; $4=$ stupor, moderate to severe hemiparesis, possibly early decerebrate rigidity, and vegetative disturbances; $5=$ deep coma, decerebrate rigidity, moribund state.

$t n=260$ in all patients and $n=202$ in surgical cases; patients who died due to the primary bleed are excluded.

‡Causes of death: 31 died of the primary bleed, 34 of a rebleed, 11 of delayed cerebral ischaemia, 2 of pneumonia, 2 of an operative complication, 2 of trauma, 1 of pulmonary embolus, and 1 of duodenal ulcus.

TABLE II - Baseline characteristics, health habits, and laboratory markers of alcohol consumption in patients with aneurysmal subarachnoid haemorrhage $(S A H)$. Values are numbers (percentages) unless otherwise indicated

\begin{tabular}{|c|c|c|c|}
\hline & $\begin{array}{c}\text { Men } \\
(n=149)\end{array}$ & $\begin{array}{l}\text { Women } \\
(n=142)\end{array}$ & $\begin{array}{l}\text { All patients } \\
(\mathrm{n}=291)\end{array}$ \\
\hline Median (range) age in years & $44 \cdot 2(21$ to 65$)$ & $47 \cdot 7(15 \text { to } 65)^{\star}$ & $45 \cdot 8(15$ to 65$)$ \\
\hline Median (range) body mass index $\left(\mathrm{kg} / \mathrm{m}^{2}\right)$ & $24 \cdot 7(16 \cdot 9$ to $39 \cdot 5)$ & $24 \cdot 0(16 \cdot 9$ to $39 \cdot 5)$ & $24 \cdot 3(16.9$ to $39 \cdot 5)$ \\
\hline \multicolumn{4}{|l|}{$\begin{array}{l}\text { Alcohol use before SAH: } \\
\text { SA }\end{array}$} \\
\hline$\geqslant 80 \mathrm{~g} / 24 \mathrm{~h}$ & $46(31)$ & $19(13) \dagger$ & $65(22)$ \\
\hline$\geqslant 150 \mathrm{~g} / 72 \mathrm{~h}$ & $46(31)$ & $16(11) \dagger$ & $62(21)$ \\
\hline$\geqslant 300 \mathrm{~g} / 1$ week & $46(31)$ & $14(10) \dagger$ & $60(21)$ \\
\hline Heavy drinkers/last year & $42(28)$ & $15(11) \dagger$ & $57(20)$ \\
\hline CAGE positive (interview score $\geqq 2$ ) & $42(28)$ & $17(12) \dagger$ & $59(20)$ \\
\hline \multicolumn{4}{|l|}{ Cigarette smoking: $\dagger$} \\
\hline Never smoked & $19(13)$ & $69(49) \dagger$ & $88(30)$ \\
\hline Former smoker & $10(7)$ & $5(4) \dagger$ & $15(5)$ \\
\hline $1-10$ cigarettes/day & $6(4)$ & $13(9) \dagger$ & $19(7)$ \\
\hline 11-20 cigarettes/day & $12(8)$ & $16(11) \dagger$ & $28(10)$ \\
\hline$>20$ cigarettes/day & $102(68)$ & $39(27) \dagger$ & $141(48)$ \\
\hline \multicolumn{4}{|c|}{ Use of non-steroidal anti-inflammatory drugs: } \\
\hline None & $75(50)$ & $69(49)$ & $144(49)$ \\
\hline Only before $\mathrm{SAH}$ & $28(19)$ & $34(24)$ & $62(21)$ \\
\hline Between SAH and admission & $34(23)$ & $25(18)$ & $59(20)$ \\
\hline Before SAH and before admission & $12(8)$ & $14(10)$ & $26(9)$ \\
\hline \multicolumn{4}{|l|}{ Salicylates in urine on admission: } \\
\hline No of samples & 119 & 104 & 223 \\
\hline Positive result & $25(21)$ & $23(22)$ & $48(22)$ \\
\hline \multicolumn{4}{|l|}{ Erythrocyte mean cell volume $(\mathrm{f})$ : } \\
\hline No of samples & 138 & 130 & 268 \\
\hline Median (range) & $95 \cdot 0(85$ to 108$)$ & $93.0(60$ to 110$) \dagger$ & $94 \cdot 0(60$ to 110$)$ \\
\hline$\geqslant 97$ & $51(37)$ & $32(25) \dagger$ & $83(31)$ \\
\hline$\geqslant 100$ & $30(22)$ & $19(15) \dagger$ & $49(18)$ \\
\hline \multicolumn{4}{|l|}{$\gamma$-Glutamyltransferase $(\mathrm{U} / \mathrm{l}):$} \\
\hline No of samples & 140 & 124 & 264 \\
\hline Median (range) & $25 \cdot 5(8$ to 586$)$ & $15 \cdot 5(6$ to 246$) \dagger$ & $21 \cdot 0(6$ to 586$)$ \\
\hline$\geqslant 45(\%)$ & $41(29)$ & $19(15) \dagger$ & $60(23)$ \\
\hline \multicolumn{4}{|l|}{ Platelet count $\left(10^{\circ} / 1\right)$ : } \\
\hline No of samples & 141 & 127 & 268 \\
\hline Median (range) & $233(67$ to 409$)$ & $243(134$ to 401$)$ & $237(67$ to 409$)$ \\
\hline$\leqslant 149$ & $14(10)$ & $7(6)$ & $21(8)$ \\
\hline
\end{tabular}

non-steroidal anti-inflammatory drugs before admission was recorded, and apart from a few exceptions these drugs were not given to patients during the hospital stay. On admission, the patients' urine was also screened qualitatively for salicylates.

Hospital records from other hospitals and general practitioners were reviewed for previous diseases. The body mass index, calculated as weight/(height) $\left(\mathrm{kg} / \mathrm{m}^{2}\right)$, was used as the index of relative weight Seventy nine $(27 \%)$ patients had hypertension (blood pressure readings had repeatedly exceeded 160/95 before haemorrhage or patients were using antihypertensive drugs)

The patient's clinical condition on admission and before operation was graded with the Glasgow coma scale $^{19}$ and the Hunt and Hess grading system (see table I) ${ }^{20}$ Subarachnoid haemorrhage was verified by computed tomography, lumbar puncture, necropsy, or operation, as applicable. Computed tomography was repeated after clinical deterioration, on discharge, and during follow up. In all patients the aneurysmal origin of the haemorrhage was confirmed.

A total of 204 of the 291 patients $(70 \%)$ were operated on. The median time from haemorrhage (day 0 ) to surgery was seven days, and $50 \%$ of the operations were performed within three to nine days from haemorrhage. Fourteen patients were operated on as an emergency because of a haematoma occupying intracerebral space.

Neurological deterioration was monitored throughout the hospital stay. Causes of a poor clinical condition and outcome were determined by repeated computed tomography scans, a routine postoperative angiogram, necropsy, or laboratory investigations. Outcome at one year was assessed with the Glasgow outcome scale. ${ }^{21}$

The data were analysed by the biomedical data package statistical programs. ${ }^{22}$ Fisher's exact two tailed test, the $\chi^{2}$ test, Spearman rank correlation coefficients, the Mann-Whitney U test, Student's $t$ test, and two way analysis of variance were used when appropriate. Independent prognostic risk factors for a poor outcome were analysed by unconditional multiple stepwise logistic regression. The simultaneous predictive value of the following variables was tested: sex; age; body mass index; hypertension; clinical grade on admission; presence of blood or intracerebral haematoma on the first computed tomography scan; occurrence of rebleeding or delayed cerebral ischaemia; amount of alcohol consumed before haemorrhage; CAGE positiveness; occurrence of heavy drinking before haemorrhage; source of information on patient's health habits; smoking habit; use of non-steroidal anti-inflammatory drugs; physical exertion during haemorrhage; deterioration due to primary bleed after admission; surgery; and timing of surgery. Adjustments were carried out by using logistic regression models.

\section{Results}

Table I shows the baseline clinical characteristics of patients and outcome at one year and table II shows the characteristics and laboratory values by sex. Eight former heavy drinkers had been abstainers for years; including them in the CAGE negative group did not affect the statistical results. Fifty six of the $59 \mathrm{CAGE}$ positive patients had used $\geqslant 300 \mathrm{~g}$ alcohol weekly during the year before haemorrhage. Three women who were CAGE positive had used 200-300 g alcohol weekly, and one man who was CAGE negative had used more than $300 \mathrm{~g}$ weekly.

Specificity of high values of erythrocyte mean cell volume and $\gamma$-glutamyltransferase as well as of thrombocytopenia for heavy drinking and CAGE positiveness was high, about $90 \%$ (table III). On the other hand, sensitivity was about $60 \%$ for high levels of 
the two first variables, but only $10-15 \%$ for thrombocytopenia.

Non-parametric correlations of continuous variables in their original form are shown in table IV. Two way analysis of variance showed that values of mean erythrocyte volume were significantly raised in heavy drinkers $(p<0.01)$ and cigarette smokers $(p<0.05)$, without interaction, but only heavy drinking increased $\gamma$-glutamyltransferase values $(\mathbf{p}<0 \cdot 01)$

Table $\mathrm{V}$ shows many univariate associations between poor outcome and other variables. Surgery TABLE III - Heavy drinking related to laboratory markers

\begin{tabular}{|c|c|c|c|c|}
\hline & \multicolumn{2}{|c|}{ Heavy drinking ${ }^{\star}$} & \multicolumn{2}{|c|}{ CAGE score } \\
\hline & No & Yes & $0-1$ & $2-4$ \\
\hline \multicolumn{5}{|c|}{ Erythrocyte mean cell volume $(\mathrm{fl})(\mathrm{n}=268)$} \\
\hline$\leqslant 96$ & 177 & 8 & 176 & 9 \\
\hline $97-99$ & 20 & 14 & 20 & 14 \\
\hline$\geqslant 100$ & 15 & $34 \dagger$ & 14 & $35 \dagger$ \\
\hline \multicolumn{5}{|c|}{$\gamma$-Glutamyltransferase $(\mathrm{U} / \mathrm{l})(\mathrm{n}=264)$} \\
\hline$<45$ & 183 & 21 & 180 & 24 \\
\hline$\geqslant 45$ & 25 & $35 t$ & 26 & $34+$ \\
\hline \multicolumn{5}{|c|}{ Platelet count $\left(10^{\circ} / 1\right)(\mathrm{n}=268)$} \\
\hline$<150$ & 13 & 8 & 14 & 7 \\
\hline$\geqslant 150$ & 199 & $48 \ddagger$ & 196 & 51 \\
\hline
\end{tabular}

was associated with outcome because surgery was performed almost entirely in good grade patients to prevent rebleeding. Only 14 of the 204 operations (7\%) were performed to improve the clinical state and outcome of the patient by evacuation of a haematoma occupying intracerebral space. Twenty one of the 61 patients with rebleeding (34\%) recovered from the rebleed and underwent surgery.

When stepwise logistic regression was used, the variables that had simultaneous significant predictive value for poor outcome were (in order of entrance in the model): Glasgow coma score on admission; occurrence of rebleeding or delayed cerebral ischaemia; surgery (inversely); and being positive on the CAGE questionnaire $(p<0.01$ for each variable). Between each step the $\chi^{2}$ value $(p<0.01)$ improved significantly, and during the stepping procedure the $\mathrm{p}$ value for goodness of fit increased from 0.57 to 0.83 . The significant predictors were the same for men and women. Predictive variables were adjusted for sex, age, and the interaction of sex and age because the men had consumed more alcohol and were younger than the women. The adjusted results are presented in table VI. The logistic model fitted well with the observed data (tests of goodness of fit, $\mathrm{p}>0.76$ ).

After the CAGE variable had been excluded from

TABLE IV-Spearman rank-order correlation coefficients for continuous baseline characteristics, laboratory variables, and outcome at one year in 291 patients with aneurysmal subarachnoid haemorrhage

\begin{tabular}{|c|c|c|c|c|c|c|c|c|c|c|c|}
\hline & \multirow[b]{2}{*}{ Age } & \multirow{2}{*}{$\begin{array}{c}\text { Body mass } \\
\text { index } \\
\left(\mathrm{kg} / \mathrm{m}^{2}\right)\end{array}$} & \multicolumn{2}{|c|}{$\begin{array}{l}\text { Alcohol consumption } \\
\text { before haemorrhage }\end{array}$} & \multirow[b]{2}{*}{$\begin{array}{l}\text { CAGE } \\
\text { score }\end{array}$} & \multirow[b]{2}{*}{$\begin{array}{c}\text { No of } \\
\text { cigarettes/day }\end{array}$} & \multirow{2}{*}{$\begin{array}{l}\text { Erythrocyte } \\
\text { mean cell } \\
\text { volume }\end{array}$} & \multirow[b]{2}{*}{$\begin{array}{l}\gamma \text {-Glutamyl- } \\
\text { transferase }\end{array}$} & \multirow[b]{2}{*}{$\begin{array}{c}\text { Platelet } \\
\text { count }\end{array}$} & \multicolumn{2}{|c|}{ Score on admission } \\
\hline & & & $\mathrm{g} / 24 \mathrm{~h}$ & $\mathrm{~g} / \mathrm{wk}$ & & & & & & $\begin{array}{l}\text { Hunt and } \\
\text { Hess }\end{array}$ & $\begin{array}{l}\text { Glasgow } \\
\text { coma scale }\end{array}$ \\
\hline Body mass index & $0 \cdot 32^{\star \star}$ & & & & & & & & & & \\
\hline \multicolumn{12}{|l|}{$\begin{array}{l}\text { Alcohol consumption } \\
\text { before haemorrhage: }\end{array}$} \\
\hline $\mathrm{g} / 24 \mathrm{~h}$ & $0 \cdot 02$ & 0.05 & & & & & & & & & \\
\hline $\mathrm{g} / \mathrm{wk}$ & $-0 \cdot 07$ & $0 \cdot 04$ & $0 \cdot 71^{\star \star}$ & & & & & & & & \\
\hline CAGE score & $0 \cdot 03$ & $0 \cdot 07$ & $0 \cdot 57^{\star \star}$ & $0 \cdot 71^{\star \star}$ & & & & & & & \\
\hline No of cigarettes/day & $-0 \cdot 10$ & $0 \cdot 04$ & $0 \cdot 29^{\star \star}$ & $0 \cdot 47^{\star \star}$ & $0 \cdot 45^{\star \star}$ & & & & . & & \\
\hline \multirow{2}{*}{\multicolumn{12}{|c|}{ Erythrocyte mean cell }} \\
\hline & -0.08 & $-0 \cdot 02$ & $0 \cdot 41^{\star \star}$ & $0 \cdot 52^{\star \star}$ & $0 \cdot 61^{\star \star}$ & $0 \cdot 42^{\star \star}$ & & & & & \\
\hline$\gamma$-Glutamyltransferase & 0.06 & $0 \cdot 22^{\star \star}$ & $0 \cdot 32^{\star \star}$ & $0 \cdot 45^{\star \star}$ & $0 \cdot 54^{\star \star}$ & $0 \cdot 37^{\star \star}$ & $0 \cdot 39^{\star \star}$ & & & & \\
\hline \multirow{2}{*}{\multicolumn{12}{|c|}{ Score on admission: }} \\
\hline & & & & & & & & & & & \\
\hline Hunt and Hess & $0 \cdot 14^{\star}$ & $0 \cdot 00$ & $0 \cdot 11$ & $0 \cdot 11$ & $0 \cdot 14^{\star}$ & -0.02 & $0 \cdot 11$ & $0 \cdot 13^{\star}$ & -0.01 & & \\
\hline Glasgow coma scale & -0.09 & 0.06 & -0.07 & $-0 \cdot 10$ & $-0 \cdot 15^{\star}$ & -0.01 & -0.08 & $-0 \cdot 13^{\star}$ & $0 \cdot 02$ & $-0.93^{\star \star}$ & \\
\hline $\begin{array}{l}\text { Glasgow outcome } \\
\text { scale }\end{array}$ & $0 \cdot 16^{\star \star}$ & $0 \cdot 08$ & 0.09 & $0 \cdot 12^{\star}$ & $0 \cdot 16^{\star \star}$ & $0 \cdot 11$ & $0 \cdot 13^{\star}$ & $0 \cdot 15^{\star}$ & 0.03 & $0 \cdot 52^{\star \star}$ & $-0 \cdot 55^{\star \star}$ \\
\hline
\end{tabular}

TABLE V-Outcome of aneurysmal subarachnoid haemorrhage related to baseline characteristics and health habits. Values are numbers (percentages) of patients unless otherwise indicated

\begin{tabular}{|c|c|c|c|}
\hline & $\begin{array}{l}\text { Independent } \\
\quad(\mathrm{n}=179)\end{array}$ & $\begin{array}{c}\text { Dependent }{ }^{\star} \\
\text { or dead } \\
(\mathrm{n}=112)\end{array}$ & p Value \\
\hline Sex ratio (male:female) & $92: 87$ & $57: 55$ & NS \\
\hline Median (range) age (years) & $44 \cdot 6(15$ to 65$)$ & $48 \cdot 5(21$ to 65$)$ & 0.0066 \\
\hline Median (range) body mass index $\left(\mathrm{kg} / \mathrm{m}^{2}\right)$ & $24 \cdot 7(16.9$ to $39 \cdot 1)$ & $25 \cdot 8(17.8$ to $39 \cdot 5)$ & 0.084 \\
\hline Hypertension & $36(20)$ & $43(38)$ & 0.0006 \\
\hline Current smoker & $113(63)$ & $75(67)$ & NS \\
\hline \multicolumn{4}{|l|}{ Alcohol consumption before haemorrhage } \\
\hline$\geqslant 80 \mathrm{~g} / 24 \mathrm{~h}$ & $36(20)$ & $29(26)$ & NS \\
\hline$\geqslant 300 \mathrm{~g} /$ week & $30(17)$ & $30(27)$ & 0.039 \\
\hline Heavy drinking & $25(14)$ & $32(29)$ & 0.0023 \\
\hline CAGE score $\geqslant 2$ & $25(14)$ & $34(30)$ & 0.0007 \\
\hline Blood on CT $\operatorname{scan}(n=282)$ & $161 / 176(91)$ & $105 / 106(99)$ & $0 \cdot 0077$ \\
\hline Intracerebral haematoma & $29(16)$ & $46(41)$ & $<0.0001$ \\
\hline \multicolumn{4}{|l|}{ Clinical grade on admission: } \\
\hline Hunt and Hess ${ }^{2 v}$ & & & $<0.0001$ \\
\hline $1-2$ & $121(68)$ & $31(28)$ & \\
\hline 3 & $52(29)$ & $25(22)$ & \\
\hline $4-5$ & $6(3)$ & $56(50)$ & \\
\hline Median (range) Glasgow coma score & $15(8-15)$ & $12(3-15)$ & $<0.0001$ \\
\hline Deterioration due to primary bleed & $22(12)$ & $39(35)$ & $<0.0001$ \\
\hline Rebleeding & $19(11)$ & $42(38)$ & $<0.0001$ \\
\hline \multicolumn{4}{|l|}{ Delayed cerebral ischaemia: } \\
\hline No of patients $\ddagger$ & 179 & 81 & \\
\hline No ischaemia & $125(70)$ & $45(56)$ & \\
\hline Reversible deficit & $36(20)$ & & \\
\hline Fixed deficit & $18(10)$ & $36(44)$ & \\
\hline Surgery & $161(90)$ & $43(38)$ & $<0.0001$ \\
\hline
\end{tabular}

«Independent $=$ good recovery or moderate disability, dependent $=$ severe disability or vegetative state, according to Glasgow outcome scale.

tHeavy drinking = average alcohol consumption of at least $300 \mathrm{~g} /$ week during the year before haemorrhage. $\ddagger$ Patients who died due to the primary bleed are excluded. the model heavy drinking during the year before haemorrhage became a significant prognostic factor for poor outcome (adjusted relative risk 3.0, 95\% confidence interval $1 \cdot 2$ to $7 \cdot 3, p=0 \cdot 017)$. When the analysis was performed without the heavy drinkers the amount of alcohol consumed shortly before haemorrhage did not affect the outcome.

When the laboratory markers were tested with clinical variables the mean erythrocyte volume was directly associated with a poor outcome after adjustment for the significant and non-significant prognostic variables mentioned above and for smoking status $(p=0.021) . \quad \gamma$-Glutamyltransferase was not significantly associated with outcome, probably because the values correlated significantly with Glasgow coma score (table IV).

Poor outcome after subarachnoid haemorrhage in heavy drinkers was due to an increase in the occurrence of severe disability and mortality. Twenty three of 59 patients positive on the CAGE questions (39\%) died, and $11(19 \%)$ were severely disabled or in a vegetative state at one year. The causes of death did not differ significantly according to alcohol consumption, but death due to rebleeding was higher than expected in patients positive on the CAGE questions. Causes of death in the CAGE positive patients were: primary bleed, seven (30\%); due to rebleeding, $11(48 \%)$; delayed cerebral ischaemia, two $(9 \%)$; and other 


\begin{tabular}{|c|c|c|c|c|c|c|}
\hline Variable & Numerical value & Coefficient ${ }^{\star}$ & $\begin{array}{l}\text { Standard } \\
\text { error }\end{array}$ & $\begin{array}{c}\text { Relative } \\
\text { risk }^{\star}\end{array}$ & $\begin{array}{l}95 \% \text { Confidence } \\
\text { interval }\end{array}$ & $\mathrm{p}$ Value \\
\hline $\begin{array}{l}\text { Glasgow coma score } \\
\text { Rebleeding } \\
\text { Delayed cerebral ischaemia } \\
\text { Surgery }\end{array}$ & $\begin{array}{l}3-15 \\
0=\text { Absent }, 1=\text { present } \\
0=\text { Absent }, 1=\text { present } \\
0=\text { No, } 1=\text { yes }\end{array}$ & $\begin{array}{l}\mathrm{C}_{1}=-0.561 \\
\mathrm{C}_{2}=1.954 \\
\mathrm{C}_{3}=2.333 \\
\mathrm{C}_{4}=-2.067\end{array}$ & $\begin{array}{l}0.094 \\
0 \cdot 478 \\
0.459 \\
0.522\end{array}$ & $\begin{array}{r}7 \cdot 06 \\
10 \cdot 31 \\
0 \cdot 13\end{array}$ & $\begin{array}{l}2.77 \text { to } 18.01 \\
4.19 \text { to } 25.35 \\
0.05 \text { to } 0.35\end{array}$ & $\begin{array}{l}<0.0001 \\
<0.0001 \\
<0.0001 \\
<0.0001\end{array}$ \\
\hline $\begin{array}{l}\text { CAGE } \\
\text { Sex } \\
\text { Age } \\
\text { Sex } \times \text { age } \\
\text { Constant }\end{array}$ & $\begin{array}{l}0=\text { Negative, } 1=\text { positive } \\
0=\text { Woman, } 1=\text { man } \\
\text { No of years } \\
\text { Product of sex and age }\end{array}$ & $\begin{array}{l}\mathrm{C}_{5}=1.495 \\
\mathrm{C}_{6}=0.735 \\
\mathrm{C}_{7}=0.005 \\
\mathrm{C}_{8}=-0.027 \\
\mathrm{C}_{0}=6.596\end{array}$ & $\begin{array}{l}0 \cdot 462 \\
1 \cdot 748 \\
0 \cdot 028 \\
0 \cdot 038 \\
1 \cdot 838\end{array}$ & $\begin{array}{l}4 \cdot 46 \\
2 \cdot 09\end{array}$ & $\begin{array}{l}1.80 \text { to } 11.03 \\
0.07 \text { to } 64 \cdot 14\end{array}$ & $\begin{array}{l}0.0014 \\
\text { NS } \\
\text { NS } \\
\text { NS }\end{array}$ \\
\hline
\end{tabular}
age)

(Poor outcome) $=$ death, vegetative state or severe disability after subarachnoid haemorrhage.

${ }^{\star}$ Coefficient and relative risk for each variable were adjusted for other variables listed in table.

tTwo or more positive responses to four questions in CAGE interview.

reasons, three $(13 \%)$. The causes of death in the 61 CAGE negative patients were: primary bleed, 24 (39\%); rebleeding, 23 (38\%); delayed ischaemia, nine $(15 \%)$; and other reasons, five $(8 \%)$.

CAGE positive patients were in a poorer clinical condition on admission (tables IV and VII); therefore they were operated on less often than others $(36 / 59$, $61 \%$ v 168/232, 72\%; $\mathrm{p}=0 \cdot 088)$. Heavy drinkers did not have episodes of rebleeding or delayed ischaemia more often than others, but these causes of deterioration were more disastrous in heavy drinkers (table VII). Heavy drinkers also had hypodense lesions on the follow up computed tomography scan consistent with cerebral infarction in areas other than previous intracerebral haematoma as often as others $(17 / 39,44 \% v$ 68/156, 44\%).

Patients who were positive on the CAGE questionnaire had not used anti-inflammatory drugs more often nor did they have salicylates in their urine on admission more often than others $(27 / 59,46 \% v 120 / 232,52 \%)$. Neither did they undergo physical exertion during haemorrhage $(13 / 56,23 \%$ v 75/225, 33\%), nor show blood on the first scan more often than others $(56 / 58$, $97 \%$ v 210-224, 94\%). However, CAGE positiveness was associated with hypertension $(23 / 59,39 \% v$ $56 / 232,24 \% ; p=0.022$ ) and the presence of an intracerebral haematoma $(21 / 59,36 \%$ v 54/232, 23\%; $\mathrm{p}=0.053$ ). After additional adjustment for hypertension, presence of intracerebral haematoma, body mass index, and smoking habit, CAGE positiveness remained a significant predictor of poor outcome

TABLE VII-Clinical grade on admission and outcome after rebleeding and delayed cerebral ischaemia according to heavy drinking. Values are number (percentage) of patients

\begin{tabular}{|c|c|c|c|c|}
\hline & \multicolumn{2}{|c|}{ Heavy drinking } & \multicolumn{2}{|c|}{ CAGE score } \\
\hline & $\begin{array}{c}\text { No } \\
(\mathrm{n}=234)\end{array}$ & $\begin{array}{c}\text { Yes } \\
(\mathrm{n}=57)\end{array}$ & $\begin{array}{c}0-1 \\
(n=232)\end{array}$ & $\begin{array}{c}2-4 \\
(n=59)\end{array}$ \\
\hline \multicolumn{5}{|l|}{$\begin{array}{l}\text { Hunt and } \mathrm{Hess}^{20} \text { grade on } \\
\text { admission }^{\star} \text { : }\end{array}$} \\
\hline I & $45(19)$ & $6(11)$ & $44(19)$ & $7(12)$ \\
\hline II & $87(37)$ & $14(25)$ & $87(37)$ & $14(24)$ \\
\hline III & $58(25)$ & $19(33)$ & $57(25)$ & $20(34)$ \\
\hline IV & $21(9)$ & $11(19)$ & $21(9)$ & $11(19)$ \\
\hline $\mathrm{V}$ & $23(10)$ & $7(12)$ & $23(10)$ & $7(12)$ \\
\hline \multicolumn{5}{|l|}{$\begin{array}{l}\text { Glasgow coma score on } \\
\text { admission }^{\star} \text { : }\end{array}$} \\
\hline $3-6$ & $23(10)$ & $10(17)$ & $23(10)$ & $10(17)$ \\
\hline $7-9$ & $12(5)$ & $3(5)$ & $12(5)$ & $3(5)$ \\
\hline $10-12$ & $14(6)$ & $5(9)$ & $14(6)$ & $5(9)$ \\
\hline $13-14$ & $52(22)$ & $18(32)$ & $51(22)$ & $19(32)$ \\
\hline 15 & $133(57)$ & $21(37)$ & $132(57)$ & $22(37)$ \\
\hline Rebleeding & $48(21)$ & $13(23)$ & $48(21)$ & $13(22)$ \\
\hline \multicolumn{5}{|l|}{ Outcome } \\
\hline Independent & 18 & $1^{\star}$ & 18 & $1^{\star}$ \\
\hline Dependent or dead & 30 & $12^{\star}$ & 30 & $12^{\star}$ \\
\hline Delayed cerebral ischaemia $†$ & $74 / 210$ & $16 / 50$ & $74 / 208$ & $16 / 52$ \\
\hline \multicolumn{5}{|l|}{ Outcome } \\
\hline Independent & 47 & 7 & 47 & 7 \\
\hline Dependent or dead & 27 & 9* & 27 & 9 \\
\hline
\end{tabular}

Heavy drinking $=$ average alcohol consumption $\geqslant 300 \mathrm{~g} /$ week during year before haemorrhage.

${ }^{\star} p<0.05$ No $v$ Yes and $0-1 v 2-4$.

tExcluding patients who died of primary bleed. (relative risk $3.9,1.5$ to $9.9, \mathrm{p}=0.0056$ ) as did heavy drinking $(2 \cdot 6,1 \cdot 1$ to $6 \cdot 4, \mathrm{p}=0.032)$ and mean erythrocyte volume $(p=0.035)$.

In surgically treated patients the independent factors predicting poor outcome were Glasgow coma score on admission $(\mathrm{p}<0.0001)$; delayed cerebral ischaemia (relative risk $9.9,3.7$ to $26.6, p<0.0001$ ) CAGE positiveness $(5.3,1.9$ to $14.7, \mathrm{p}<0.01)$; and increase in body mass index $(\mathrm{p}<0 \cdot 5)$.

Smoking affected neither outcome nor incidence or severity of rebleeding or delayed ischaemia. Use of non-steroidal anti-inflammatory drugs before admission did not affect the presence of rebleeding or delayed ischaemia, but those patients who had salicylates in their urine on admission had delayed ischaemia with fixed neurological deficit more rarely than those without salicylates in the urine $(5 / 45,11 \% v 38 / 156$, $24 \% ; p=0.056$ ).

\section{Discussion}

The outcome after aneurysmal subarachnoid haemorrhage is determined by the severity of bleeding assessed by the clinical condition and amount of subarachnoid, intracerebral, and intraventricular blood shown on computed tomography, as well as by the occurrence of rebleeding or delayed cerebral ischaemia ${ }^{1-6}$ The independent role of previous health habits and hypertension in the outcome has been unknown. The patient population in this study was unselected, as seen by the number of patients who died as a result of the initial haemorrhage and early rebleeding. However, $10-15 \%$ of patients do not reach medical attention after subarachnoid haemorrhage. ${ }^{1-3}$

It is well known that heavy drinkers tend to deny their problems. This may cause bias due to underestimation of alcohol intake. Therefore, three separate means were used to identify alcohol consumption in this study. Two methods were based on interview: calculation of the amount of alcohol consumed within the year before the subarachnoid haemorrhage, and the CAGE interview, which relates to abnormal drinking behaviour (for example, drinking on waking) and alcohol induced problems, rather than merely the amount of alcohol consumed. ${ }^{17}{ }^{18} \mathrm{CAGE}$ positiveness is sensitive for detection of heavy drinking and alcoholism (90\%), and its specificity is $75-80 \% \cdot{ }^{17-18}$ The third method used was determination of laboratory markers $-\gamma$-glutamyltransferase concentration and erythrocyte mean cell volume-to detect excessive drinkers. The reported sensitivity of high values of these markers for heavy drinking has ranged from $30 \%$ to $90 \%$, but specificity has usually been high $(80-99 \%) .{ }^{1823-26}$

When interviewed, patients in good clinical condition might possibly underestimate alcohol intake more than would family members of patients in poor condition. This could lead to a biased increase in risk 
for poor outcome in heavy drinkers. However, CAGE positiveness and results of laboratory markers accorded with the estimated alcohol intake. Heavy drinkers seem to be in a poorer condition after haemorrhage than others. To reduce underestimation I recorded the greater reported values obtained from either the patient or family member even though I did not observe any decisive differences between the reported values during a careful interview.

Poor outcome in heavy drinkers was caused mainly by an increase in mortality and morbidity due to rebleeding and delayed ischaemia, although occurrence and time of onset of rebleeding and delayed ischaemia were not affected by drinking habits. Hypodense lesions on the follow up computed tomography scan in areas other than the previous intracerebral haematoma were as common in heavy drinkers as in others. These lesions can be symptomatic or symptomless depending on the location and size of the lesion. ${ }^{627}$ Besides causing delayed cerebral ischaemia and intracerebral haematoma, surgery can cause hypodense lesions that have been attributed to spatula pressure or injury to penetrating arteries during operation. ${ }^{627}$

Heavy drinking and ethanol withdrawal can predispose to poor outcome after subarachnoid haemorrhage through various mechanisms. These include the effects of blood pressure, ${ }^{28-30}$ platelet function, ${ }^{31}{ }^{32}$ clotting factors, ${ }^{33}$ alcohol induced cardiac arrhythmias, ${ }^{34}$ and changes in cerebral blood flow. ${ }^{35}$ Alcohol consumption, independently of other factors, raises blood pressure, as does alcohol withdrawal transiently..$^{28-30}$

Long term severe heavy drinking can cause thrombocytopenia, reduced platelet aggregability and thromboxane formation capacity, increased prostacyclin production in the endothelium, and defects of clotting factors. ${ }^{31-33}$ These, possibly together with hypertension, could explain the severity of rebleeding and presence of intracerebral haematoma in heavy drinkers. Stopping alcohol abuse results in rebound thrombocytosis ${ }^{3132}$ and increased thromboxane formation by platelets ${ }^{32}$ within two weeks, thus favouring thrombosis formation. ${ }^{32}$ In this study heavy drinking and the occurrence and severity of rebleeding or delayed ischaemia were not associated with platelet count on admission. Increased platelet function and thromboxane formation capacity have recently been associated with delayed cerebral ischaemia after subarachnoid haemorrhage. ${ }^{27} 3637$

This research was supported in part by a grant from the Maire Taponen Foundation, Helsinki.

\footnotetext{
1 Kassell NF, Drake CG. Timing of aneurysm surgery. Neurosurgery 1982;10: $514-9$.

2 Bonita R, Thomson S. Subarachnoid hemorrhage: epidemiology, diagnosis, Bonita R, Thomson S. Subarachnoid hemorrhage:
management, and outcome. Stroke 1985;16:591-4.

management, and outcome. Stroke 1985;16:591-4.
3 Juvela S. Minor leak before rupture of an intracranial aneurysm and uvela S. Minor leak before rupture of an intracranial aneurysm and
subarachnoid hemorrhage of unknown etiology. Neurosurgery 1992;30:7-11. subarachnoid hemorrhage of unknown etiology. Neurosurgery 1992;30:7-11.
4 Adams HP Jr, Kassell NF, Torner JC, Haley EC Jr. Predicting cerebral ischemia after aneurysmal subarachnoid hemorrhage: influences of clinical condition, CT results, and antifibronolytic therapy. Neurology 1987;37: 1586-91

5 Hijdra A, van Gijn J, Nagelkerke NJ, Vermeulen M, van Crevel H. Prediction
}

of delayed cerebral ischemia, rebleeding, and outcome after aneurysmal subarachnoid hemorrhage. Stroke 1988;19:1250-6.

6 Öhman J, Servo A, Heiskanen O. Risk factors for cerebral infarction in good grade patients after aneurysmal subarachnoid hemorrhage and surgery: a prospective study. I Neurosurg 1991;74:14-20.

7 Hillbom $M$, Kaste $M$. Alcohol intoxication: a risk factor for primary subarachnoid hemorrhage. Neurology 1982;32:706-11.

8 Donahue RP, Abbott RD, Reed DM, Yano K. Alcohol and hemorrhagic stroke: the Honolulu heart program. FAMA 1986;255:2311-4.

9 Stampher MJ, Colditz GA, Willett WC, Speizer FE, Hennekens CH. A prospective study of moderate alcohol consumption and the risk of coronary disease and stroke in women. $N$ Engl F Med 1988;319:267-73.

10 Camargo CA. Moderate alcohol consumption and stroke: the epidemiologic evidence. Stroke 1989;20:1611-26.

11 Shaper AG, Phillips AN, Pocock SJ, Walker M, Macfarlane PW. Risk factors for stroke in middle aged British men. BMf 1991;302:1111-5.

12 Bell BA, Symon L. Smoking and subarachnoid haemorrhage. BMF 1979; 577-8.

13 Sacco RL, Wolf PA, Bharucha NE, Meeks SL, Kannel WB, Charette LJ, et al. Subarachnoid and intracerebral hemorrhage: natural history, prognosis,
and precursive factors in the Framingham study. Neurology 1984;34:847-54.

14 Bonita R. Cigarette smoking, hypertension and the risk of subarachnoid hemorrhage: a population-based case-control study. Stroke 1986;17:831-5.

15 Colditz GA, Bonita R, Stampfer MJ, Willett WC, Rosner B, Speizer FE, et al. Cigarette smoking and risk of stroke in middle-aged women. $N$ Engl $f \mathrm{Med}$ 1988;318:937-41

16 Steering Committee of the Physicians' Health Study Research Group. Final report on the aspirin component of the ongoing physicians' health study. N Engl f Med 1989;321:129-35.

17 Mayfield D, McLeod G, Hall P. The CAGE questionnaire: validation of a new alcoholism screening instrument. Am F Psychiatry 1974;131:1121-3.

18 Bernadt MW, Mumford J, Taylor C, Smith B, Murrav RM. Comparison of questionnaire and laboratory tests in the detection of excessive drinking and alcoholism. Lancet 1982;i:325-8.

19 Teasdale G, Jennett B. Assessment of coma and impaired consciousness. A practical scale. Lancet 1974; ;i:81-4.

20 Hunt WE, Hess RM. Surgical risk as related to time of intervention in the repair of intracranial aneurysms. I Neurosurg 1968;28:14-20.

21 Jennett $B$, Bond $M$. Assessment of outcome after severe brain damage. A practical scale. Lancet 1975; ;:480-4.

22 Dixon WJ, ed. BMDP statistical software. Berkeley: University of California Press, 1988.

23 Kristenson H, Trell E, Fex G, Hood B. Serum gammaglutamyltransferase: statistical distribution in a middle-aged male population and evaluation of alcohol habits in individuals with elevated levels. Prev Med 1980;9:108-19.

24 Morgan MY, Camilo ME, Luck W, Sherlock S, Hoffbrand AV. Macrocytosi in alcohol-related liver disease: its value for screening. Clin Lab Haematol 1981;3:35-44.

25 Papoz L, Warnet J-M, Pequignot G, Eschwege E, Claude JR, Schwartz D. Alcohol consumption in a healthy population: relationship to gammaglutamyl transferase activity and mean corpuscular volume. $7 A M A 1981$ 245:1748-51.

26 Monteiro MG, Masur J. Diagnostic of alcoholism: how useful is the combination of gamma glutamyl transferase with different biochemical combination of gamma glutamyl transferas
markers? Drug Alcohol Depend 1985;16:31-7.

27 Juvela S. Cerebral infarction and release of platelet thromboxane after subarachnoid hemorrhage. Neurosurgery 1990;27:929-35.

28 Klatsky AL, Friedman GD, Siegelaub AB, Gerard MJ. Alcohol consumption and blood pressure: Kaiser-Permanente multiphasic health examination data. N Engl f Med 1977;296:1194-200.

29 Puddey IB, Beilin LJ, Vandongen R, Rouse IL, Rogers P. Evidence for a direct effect of alcohol consumption in normotensive men: a randomized controlled trial. Hypertension 1985;7:707-13

30 Intersalt Cooperative Research Group. Intersalt: an international study of electrolyte excretion and blood pressure. Results for 24 hour urinary sodium and potassium excretion. BMJ 1988;297:319-28.

31 Haselager EM, Vreeken J. Rebound thrombocytosis after alcohol abuse: possible factor in the pathogenesis of thromboembolic disease. Lancet 1977;i:774-5.

32 Hillbom M, Neiman J. Platelet thromboxane formation capacity after ethanol withdrawal in chronic alcoholics. Haemostasis 1988;18:170-8.

33 Ragni MV, Lewis JH, Spero JA, Hasiba U. Bleeding and coagulation abnormalities in alcoholic cirrhotic liver disease. Alcoholism Clin Exp Res 1982;6:267-74.

34 Ettinger PO, Wu CF, De La Cruz CJ Jr, Weisse AB, Ahmed SS, Regan TJ. Arrhythmias and the "holiday heart": alcohol-associated cardiac rhythm disorders. Am Heart f 1978;95:555-62.

35 Berglund $M$, Risberg J. Regional cerebral blood flow during alcohol with drawal. Arch Gen Psychiatry 1981;38:351-5.

36 Juvela S, Hillbom M, Kaste M. Platelet thromboxane release and delayed cerebral ischemia in patients with subarachnoid hemorrhage. $I$ Neurosur 1991;74:386-92.

37 Juvela S. Platelet aggregation and thromboxane release in primary subarachnoid hemorrhage [dissertation]. Helsinki: University of Helsinki 1991.

(Accepted 29 April 1992)

Dr. Grainger, of Chester, reports to us that the bandages were removed from Mr. Gladstone's eye on Tuesday night. The wound of the cornea was healed. Dr. Grainger, who travelled with the right hon. gentleman to Lancaster on Wednesday, states that he was in very good health and spirits, and bore the journey well. As to the precise nature

of the injury, Dr. Grainger informs us that when seen an hour after his accident Mr. Gladstone was suffering a good deal of pain from his left eye, the lower lid was bruised, and there was a small wound on the side of the nose. There was an irregular jagged cut or scratch on the outer side of the cornea, about a quarter of an inch in length; the epithelium was stripped from the surface of the cornea to a little beyond the edge of the pupil. (BMF 1892;ii:33) 